\title{
Selected Fuel Properties of Alcohol and Rapeseed Oil Blends
}

\author{
Carolin Nuortila *, Riikka Help, Katriina Sirviö, Helena Suopanki, Sonja Heikkilä and \\ Seppo Niemi
}

School of Technology and Innovations, University of Vaasa, P.O. Box 700, FI-65101 Vaasa, Finland; riikka.help@outlook.com (R.H.); katriina.sirvio@univaasa.fi (K.S.); helena.suopanki@gmail.com (H.S.); sonja.heikkila@univaasa.fi (S.H.); seppo.niemi@univaasa.fi (S.N.)

* Correspondence: carolin.nuortila@univaasa.fi; Tel.: +358-29-449-8244

Received: 16 June 2020; Accepted: 22 July 2020; Published: 25 July 2020

\begin{abstract}
The alcohols ethanol and 1-butanol are interesting options as blending components for renewable fuels. We studied whether it is possible to mix these alcohols with a little refined material, rapeseed oil, to obtain stable fuel samples. At room temperature, the stable samples consisted of rapeseed oil blended with butanol at 5 vol- $\%, 10$ vol- $\%, 20$ vol- $\%, 30$ vol- $\%$ and one sample of rapeseed oil with 5 vol- $\%$ of ethanol. The samples' fuel properties analysed were kinematic viscosity $\left(\right.$ at $\left.40{ }^{\circ} \mathrm{C}\right)$, density $\left(\right.$ at $15{ }^{\circ} \mathrm{C}$ ) and surface tension. Cold filter plugging point was measured for rapeseed oil with 20 vol- $\%$ and 30 vol- $\%$ of butanol. Stability of butanol or ethanol and rapeseed oil blends can be achieved at the studied volumes. The density of neat rapeseed oil and all the alcohol-rapeseed oil blends met the requirements set for residual marine fuels. The $30 \mathrm{vol}-\%$ butanol-rapeseed oil blend met the requirements for distillate marine oil for density, and almost for kinematic viscosity. The blends appeared most suitable for power plants and marine engines. More detailed analyses of their properties are needed before recommendations for use can be given.
\end{abstract}

Keywords: alternative fuels; biofuels; blend properties; renewable energy

\section{Introduction}

The need to develop alternative, renewable fuels is a response to the challenges set by climate change, expected depletion of fossil fuel sources, mankind's steadily increasing energy demand and a growing world population. Development of fuels from renewable resources is urgently sought to reduce carbon emissions. The European Union (EU) has agreed to achieve the consumption of $32 \%$ renewable energy by 2030 in order to abate greenhouse gas emissions (GHG) [1], but the current share of renewables in, for example, liquid fuels production, lies at only about $2 \%$ worldwide [2].

Climate change and the expected depletion of fossil fuel sources make it imperative to research alternative fuels [3]. While technically feasible, many alternative fuels are still more expensive to produce than fossil fuels $[4,5]$. However, the value of alternative fuels might soon change due to diminishing availability of fossil resources. Moreover, fossil fuels are not equally available in all regions around the world. Development of renewable, locally produced and cost-effective fuels could help increase self-sufficiency of energy generation. This would support goals of sustainable development and equal opportunities for all people [6].

Despite the negative reputation that diesel engines have gained during the past decade or so, compression ignition (CI) technology is both efficient and reliable in heavy-duty machines, the transport sector and power generation [7]. Accordingly, CI engines probably will not be completely replaced in the near future. CI engines can be fuelled with fossil and renewable fuels, thus, for the time being, 
new fuels need to have properties compatible with existing engines, they need to comply with emission limits and they should be sustainable in production.

One of the oldest renewable fuels is vegetable oil. Investigations of its use in CI engines with or without adaptations have shown positive, negative or neutral effects on combustion and emission parameters in comparison with fossil diesel [8-10]. Vegetable oil is still of interest in developing fuel blends for CI engines [reviewed in 9,10]. One of the biggest challenges with untransformed (neat) vegetable oils is their high viscosity [11]. For optimal engine operation, fuel viscosity has to conform with certain values set in international and national standards. While the EN 590 standard for automotive fuel requires viscosity to be in the range of $2.00-4.50 \mathrm{~mm}^{2} \mathrm{~s}^{-1}$ [12], the viscosity of vegetable oils has been measured to be 10 times higher [13]. High viscosity of a fuel can cause pumping losses during injection leading to a reduction in injection pressure and consequently poorer atomisation of the fuel, affecting combustion [11]. High viscosity may also cause carbon deposits and can lead to clogging of fuel lines [14]. Fuel density and surface tension are also important fuel properties in relation to fuel injection and drop formation. The density of the fuel affects the mass injected into the combustion chamber, since the injection system is usually set to deliver a certain volume of fuel [11]. Thus, variation in fuel density leads to variation in injected mass, impacting combustion. Surface tension influences fuel atomisation, in turn influencing combustion [11]. Cold filter plugging point (CFPP), defined as the temperature at which a fuel is no longer passing through a standardised filter within a given time, is another property that is poorly met by neat vegetable oils and needs to be addressed for fuels used in temperate and cold climates to ensure that the fuel passes through a fine-mesh filter before entering the injection pump [11]. There are several ways of modifying the properties of vegetable oils, including chemical conversion via transesterification, blending two or even more fuels with each other or heating [15].

Rapeseed oil is a fully renewable product and is already used as feedstock for biodiesel production, which is then blended with fossil diesel. Diesel blends for transport have been on the European market already for more than 20 years with a maximum share of 7 vol- $\%$ of biodiesel [12]. Biodiesel has been produced on an industrial scale in Europe since 1992 [16]. However, the process of transesterification into biodiesel not only consumes chemicals and energy, but also produces waste products such as glycerol [17]. Therefore, it would be beneficial if neat vegetable oils or blends of vegetable oil and, e.g., alcohols, would be suitable for fuelling existing diesel engines without needing extensive chemical conversion. Research results have shown that blending rapeseed oil with higher alcohols can lead to a pronounced reduction in viscosity [14].

Alcohols produced from renewable sources are of great interest as fuel components. Alcohols are light components, volatile and evaporate easily. The alcohol blend's stability is affected by the molecular interactions between alcohol components and the other fuel used for blending. Fuel blends need to be stable over time and in variable temperature conditions to ensure reliable fuel properties during injection and combustion. Formation of phases of different components due to dissolution or demixing could lead to serious operating problems in an engine [11]. Blends of ethanol and diesel can be stabilised by adding an emulsifier or a co-solvent to the blend to secure the solubility of ethanol in diesel [18]. Alcohols can be used in internal combustion engines, and the blend of alcohol with gasoline is commercially exploited. However, not all alcohols are equally suitable for blending. Light alcohols such as methanol and ethanol have proven less stable in blends with vegetable oil [19]. Interest in butanol as a fuel component has risen during recent years because butanol has a higher lower heating value, a higher cetane number and higher viscosity than ethanol or methanol [20].

It is necessary to either adjust CI engines to run on fuels that have different properties than fossil diesel, or to adjust the properties of renewable fuels to fit the operability of CI engines. This study evaluates mixing ethanol and butanol with rapeseed oil. For the blends that were considered stable, it reports kinematic viscosity, density, surface tension and CFPP. These key properties are assessed and compared with standards for EU automotive fuels, biodiesel and marine fuels. 


\section{Materials and Methods}

Blends were prepared using the following biofuels: ethanol (denatured, 91.2\% Etax A12) from Altia, Finland; butanol (1-Butanol $\geq 98.5 \%$, GPR RECTAPUR ${ }^{\circledR}$ ) from VWR International, France; and rapeseed oil (100\% rapeseed oil) from Avena Kantvik, Finland. All three were commercial products.

For testing stability, alcohol-rapeseed oil blends with different proportions of alcohol were prepared in total volumes of 40 to $50 \mathrm{~mL}$ in a measuring cylinder, shaken by hand in a glass bottle and poured into a measuring cylinder for inspection. The blends were evaluated by sight and photographed. The cylinders were tightly sealed and stored for several days to up to two weeks at room temperature, during which time they were repeatedly inspected. After identifying the stable alcohol-rapeseed oil combinations, blends of ethanol and rapeseed oil and butanol and rapeseed oil were prepared to final volumes of $200 \mathrm{~mL}$, which were used to measure their physical and chemical properties.

\subsection{Kinematic Viscosity and Density}

Kinematic viscosity and density were measured with a Stabinger SVM 3000 rotational viscometer (Anton Paar $\mathrm{GmbH}$, Austria). The method for the measurement of kinematic viscosity at $40^{\circ} \mathrm{C}$ is according to standard EN ISO 3104; the measurement of the density at $15^{\circ} \mathrm{C}$ is according to standard EN ISO 12185. The kinematic viscosity measurement is based on torque and speed measurements. The device has a density measuring cell that employs the oscillating U-tube principle. [21]

The device calculates the dynamic viscosity, $\eta$ (mPa s), from the rotor speed by Equation (1):

$$
\eta=\frac{K}{\frac{n_{2}}{n_{1}}-1}
$$

where $K$ is a constant, $n_{1}$ is the speed of the measuring rotor $\left(\mathrm{mm} \mathrm{s}^{-1}\right)$ and $n_{2}$ is the speed of the measuring tube $\left(\mathrm{mm} \mathrm{s}^{-1}\right)$.

The kinematic viscosity, $K V\left(\mathrm{~mm}^{2} \mathrm{~s}^{-1}\right)$, was calculated automatically based on these measurements according to Equation (2):

$$
K V=\frac{\eta}{\rho}
$$

where $\eta$ is dynamic viscosity (mPa s) and $\rho$ is density $\left(\mathrm{g} \mathrm{cm}^{-3}\right)$ [22].

\subsection{Surface Tension}

Surface tension was measured with a Lauda tensiometer TD 2 (Lauda Dr. R. Wobser GmbH \& CO.KG, Germany) according to the manufacturer's instructions [23]. The tensiometer measures the force that is needed to release a ring from the measured liquid, in other words the force $d w$ that is needed to change the area, $\sigma$, an infinitesimal amount, $d \sigma$ (Equation (3)):

$$
d w=\gamma \cdot d \sigma
$$

where the surface density, $\gamma$, is a proportionality coefficient. The results are given in unit $\mathrm{mN} \mathrm{m}^{-1}[23,24]$.

\subsection{Cold Filter Plugging Point}

The cold filter plugging point (CFPP) was determined in an automatic CFPP measurement with a Callisto 100 instrument (Anton Paar GmbH, Austria). The CFPP value is the highest temperature at which a fuel fails to pass through a standardised test filter in a specified time when cooled under specified conditions [25]. The temperature during the test is lowered in steps of $1.0^{\circ} \mathrm{C}$. The measurement method is in accordance with standard EN 116 [26].

The results are presented as the arithmetic means of two replicate measurements. The relative standard deviations (RSD) for kinematic viscosity was $<1 \%$, for density $<1 \%$ and for CFPP $6.3 \%$. For surface tension, the RSD was not measured. 


\section{Results}

All of the butanol-rapeseed oil blends ( 5 vol- $\%, 10$ vol- $\%$, 20 vol- $\%, 30$ vol- $\%$ ) were stable. However, only the $5 \%$ ethanol- $95 \%$ rapeseed oil blend was considered stable. By increasing the proportion of the lower-carbon alcohol ethanol in the blend, stability could not be achieved. Even a small increase of ethanol to 8 vol- $\%$ caused the mixture to form phase separation soon after mixing. One possible reason for this failure might have been the water content of $5.8 \mathrm{w}-\%$ of the ethanol and the presence of $3.0 \mathrm{w}-\%$ $\mathrm{t}$-butanol. However, mixing butanol with ethanol and rapeseed oil did not result in stable blends either in the present study. The tested alcohol-rapeseed oil combinations are presented in Table 1 and depicted in Figure 1. Initial turbidity in sample E5-RSO disappeared after some days.

For the E5-RSO blend and the different butanol-rapeseed oil blends that proved stable, we report kinematic viscosity, density and surface tension, and for two butanol-rapeseed oil blends, also the cold filter plugging point. Adding ethanol or butanol to rapeseed oil clearly decreased kinematic viscosity (Figure 2), density (Figure 3) and surface tension (Figure 4) in the blends as compared to the neat rapeseed oil. The largest reduction was noticed for kinematic viscosity and the smallest for density.

Table 1. Alcohol-rapeseed oil mixtures tested for stability.

\begin{tabular}{|c|c|c|c|}
\hline & $\begin{array}{l}\text { Alcohol and Rapeseed Oil } \\
\text { Blending Ratio (v-v\%) }\end{array}$ & $\begin{array}{l}\text { Abbreviation } \\
\text { for Blend }\end{array}$ & $\begin{array}{l}\text { Comment on } \\
\text { Appearance }\end{array}$ \\
\hline Mixtures & $\begin{array}{l}\text { 8\% Ethanol-92\% rapeseed oil } \\
\text { 10\% Ethanol-7.5\% butanol-82.5\% rapeseed oil } \\
20 \% \text { Ethanol-15\% butanol-65\% rapeseed oil }\end{array}$ & & $\begin{array}{l}\text { phase separation } \\
\text { phase separation } \\
\text { phase separation }\end{array}$ \\
\hline Stable blends & $\begin{array}{l}5 \% \text { Ethanol-95\% rapeseed oil } \\
5 \% \text { Butanol-95\% rapeseed oil } \\
10 \% \text { Butanol-90\% rapeseed oil } \\
20 \% \text { Butanol- } 80 \% \text { rapeseed oil } \\
30 \% \text { Butanol-70\% rapeseed oil }\end{array}$ & $\begin{array}{l}\text { E5-RSO } \\
\text { BU5-RSO } \\
\text { BU10-RSO } \\
\text { BU20-RSO } \\
\text { BU30-RSO }\end{array}$ & somewhat turbid \\
\hline
\end{tabular}

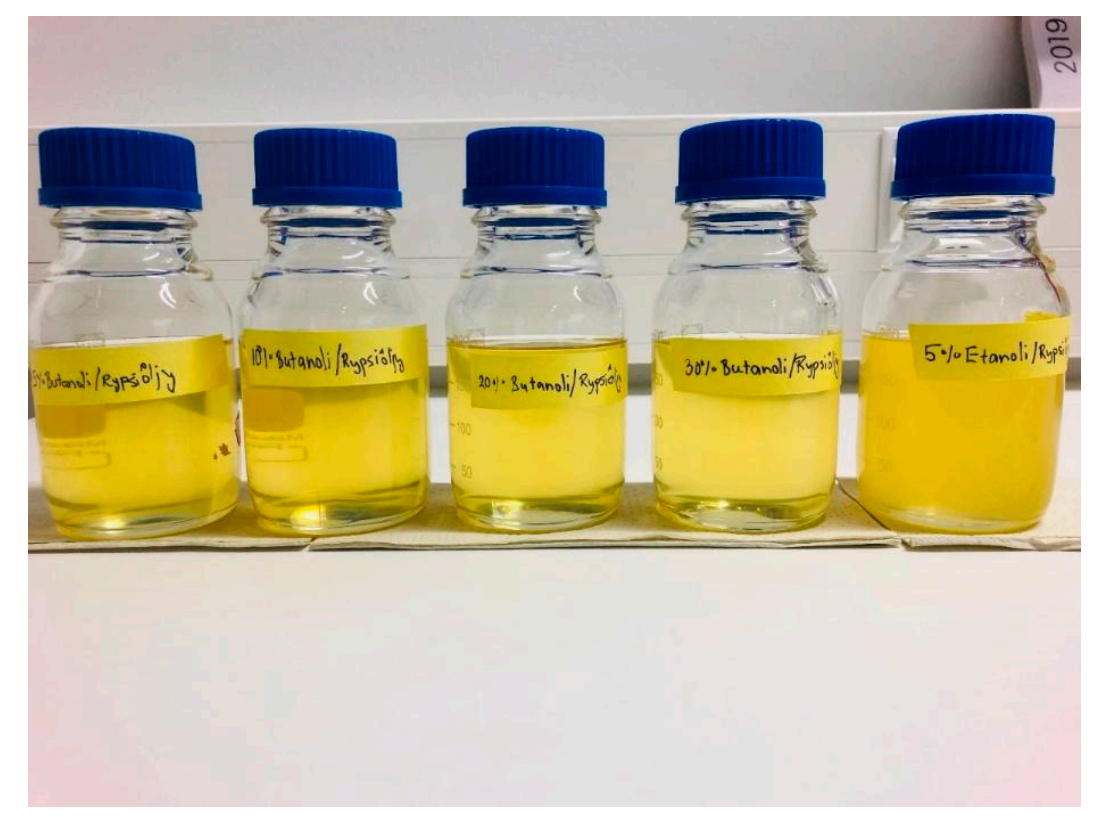

Figure 1. Ready blends (from left to right) of BU5-RSO, BU10-RSO, BU20-RSO, BU30-RSO and E5-RSO (photograph by Riikka Help). 


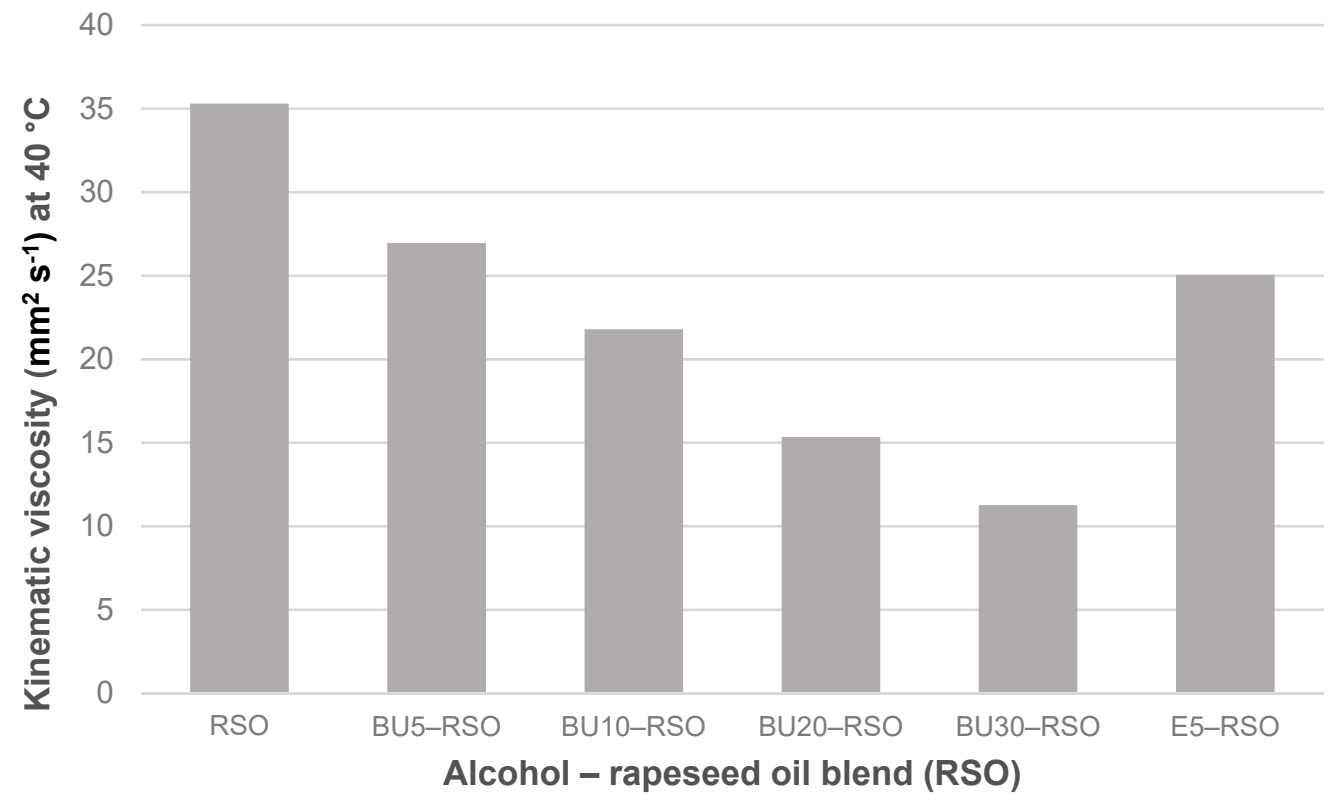

Figure 2. Kinematic viscosity measured at $40^{\circ} \mathrm{C}$ for rapeseed oil, butanol-rapeseed oil and ethanolrapeseed oil blends.

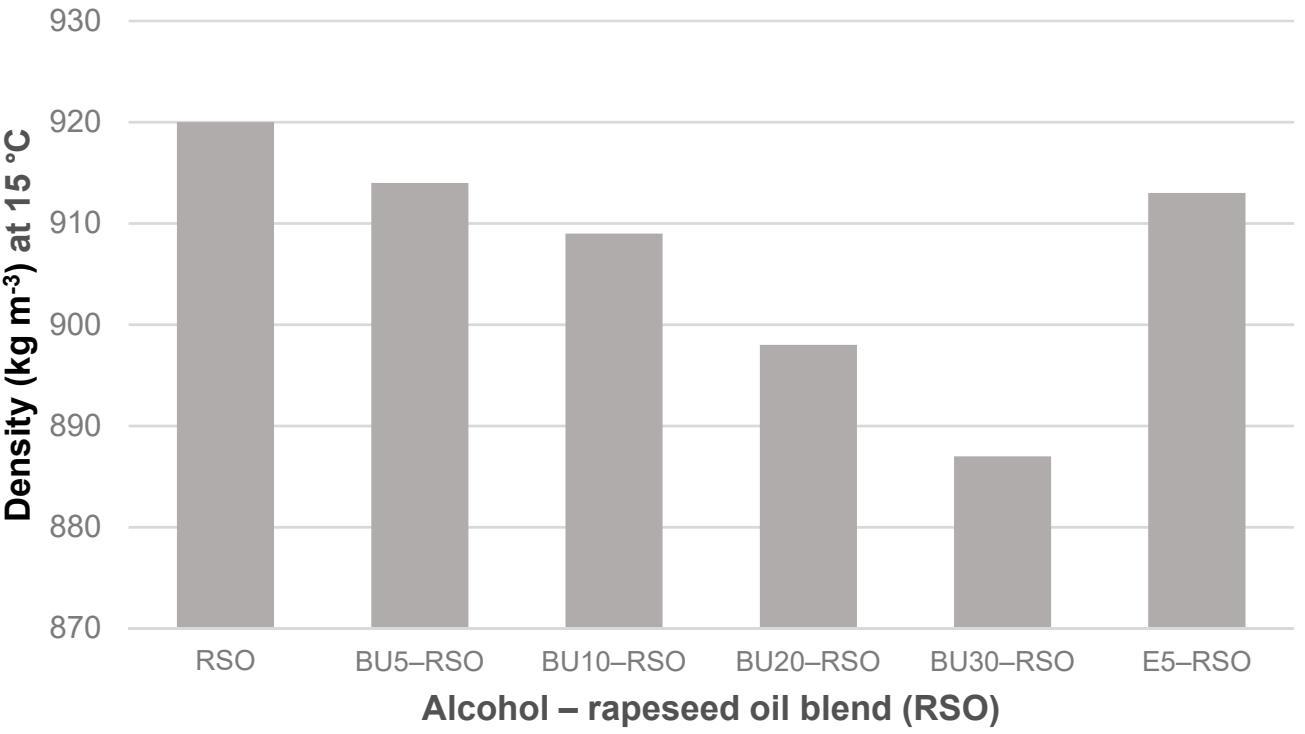

Figure 3. Density measured at $15^{\circ} \mathrm{C}$ for rapeseed oil, butanol-rapeseed oil and ethanol-rapeseed oil blends. Note that the y-axis scale starts at $870 \mathrm{~kg} \mathrm{~m}^{-3}$.

Blending rapeseed oil with ethanol or butanol led to a reduction in kinematic viscosity in all of the blends. The effect was strongest in the BU30-RSO blend in which kinematic viscosity was reduced by $68 \%$, from $35.30 \mathrm{~mm}^{2} \mathrm{~s}^{-1}$ for neat rapeseed oil to $11.26 \mathrm{~mm}^{2} \mathrm{~s}^{-1}$ for BU30-RSO. Kinematic viscosity of the E5-RSO blend was $25.05 \mathrm{~mm}^{2} \mathrm{~s}^{-1}$ and thus slightly lower than the value for BU5-RSO of $26.96 \mathrm{~mm}^{2} \mathrm{~s}^{-1}$.

Density gradually decreased along with an increase of butanol vol- $\%$. It fell from $920 \mathrm{~kg} \mathrm{~m}^{-3}$ for the rapeseed oil to $887 \mathrm{~kg} \mathrm{~m}^{-3}$ for the BU30-RSO blend, equalling a reduction of 3.5\%. The E5-RSO blend showed only a slight reduction in density $(<1 \%)$ and its value of $913 \mathrm{~kg} \mathrm{~m}^{-3}$ was almost identical to that of the BU5-RSO blend $\left(914 \mathrm{~kg} \mathrm{~m}^{-3}\right)$.

Temperature during the surface tension measurements was in the range from $22.2{ }^{\circ} \mathrm{C}$ to $22.5^{\circ} \mathrm{C}$. Surface tension was reduced from $32.9 \mathrm{mN} \mathrm{m}^{-1}$ in rapeseed oil to $26.4 \mathrm{mN} \mathrm{m}^{-1}$ in the BU30-RSO blend, 
equating to a reduction of $19.8 \%$. The addition of 5 vol- $\%$ ethanol to rapeseed oil had a stronger effect than the addition of 5 vol- $\%$ butanol. In fact, blending $5 \%$ butanol with rapeseed oil had almost no effect at all on surface tension as compared to neat rapeseed oil. The BU20-RSO blend and the E5-RSO blend showed almost the same surface tension with $27.9 \mathrm{mN} \mathrm{m}^{-1}$ and $27.7 \mathrm{mN} \mathrm{m}^{-1}$, respectively, values that were circa $15 \%$ lower than shown by the neat rapeseed oil.

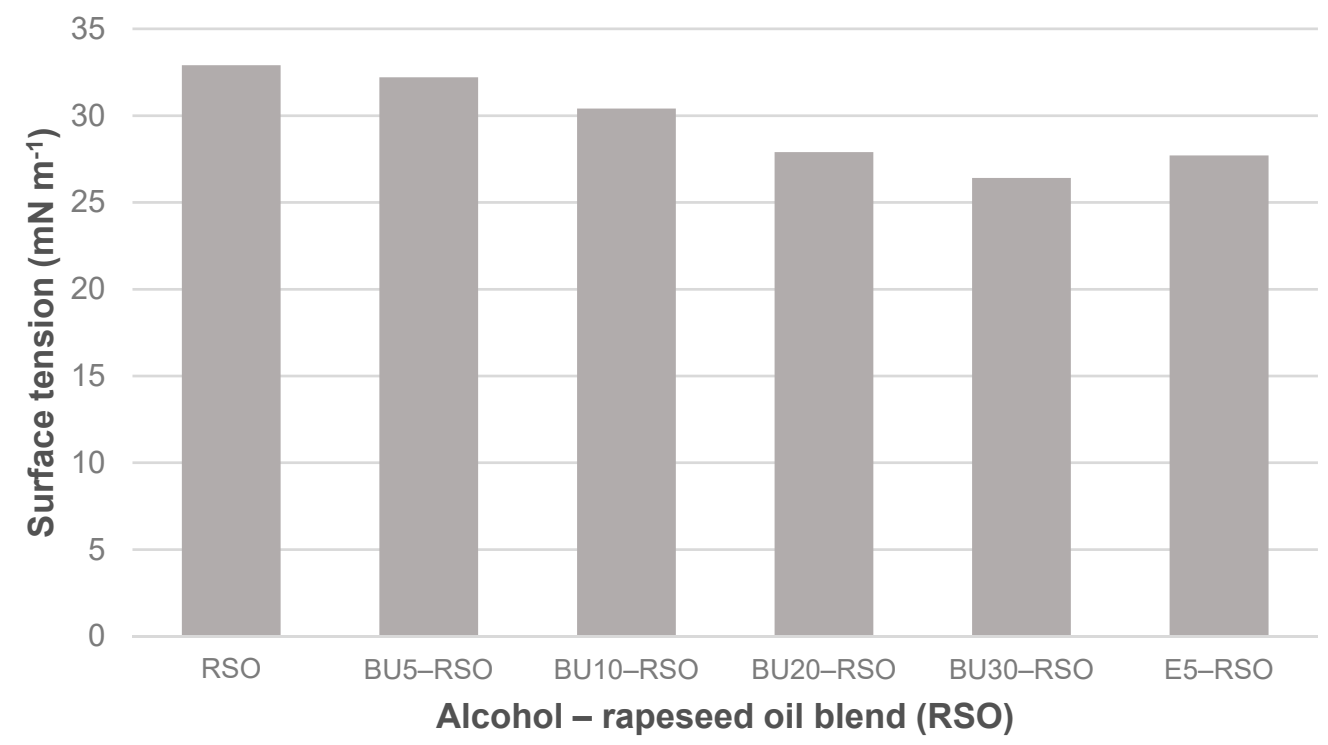

Figure 4. Surface tension measured for rapeseed oil, butanol-rapeseed oil and ethanol-rapeseed oil blends.

Cold filter plugging point could be measured only for two of the butanol-rapeseed oil blends. CFPP was reached at $-6{ }^{\circ} \mathrm{C}$ and at $-13^{\circ} \mathrm{C}$ in the BU20-RSO blend and the BU30-RSO, respectively. The measuring method was not suitable for the other samples.

\section{Discussion}

Mixing rapeseed oil with butanol in volumes from 5 vol- $\%$ up to 30 vol- $\%$ resulted in stable blends. Rapeseed oil mixed with ethanol at 5 vol- $\%$ also showed a stable blend. Mixing ethanol at 8 vol- $\%$ with RSO resulted in phase separation, and this might have been caused by the presence of water and butanol in the commercial ethanol product. Nevertheless, Jin et al. [19] reported that even blends of soybean and anhydrous ethanol led directly to phase separation. On the other hand, in the study by Jin et al. [19] butanol could be used to form stable one-phase systems with soybean and ethanol depending on volume ratios. Lapuerta et al. [27] reported viscosity for ethanol-biodiesel and ethanol-diesel blends for ethanol concentrations of up to 75 vol- $\%$ without addition of stabilisers. This suggests that the blends were stable even with high ethanol concentrations.

Kinematic viscosity of RSO was efficiently reduced by mixing with both ethanol and butanol. Laza and Bereczky [14] investigated basic fuel properties of rapeseed oil-higher alcohols (butanol and propanol) blends for $\mathrm{v}-\mathrm{v}$ ratios of $5 \%, 10 \%$ and $20 \%$. In their study, kinematic viscosity dropped from circa $37 \mathrm{~mm}^{2} \mathrm{~s}^{-1}$ in neat rapeseed oil to circa $17 \mathrm{~mm}^{2} \mathrm{~s}^{-1}$ in the blend of $20 \%$ 1-butanol with rapeseed oil. In our study, the kinematic viscosity was slightly lower for neat rapeseed oil $\left(35.3 \mathrm{~mm}^{2} \mathrm{~s}^{-1}\right)$ and for all the blends with 1-butanol when compared with the results measured by Laza and Bereczky [14]). Adding butanol to jatropha oil reduced kinematic viscosity from $36.55 \mathrm{cSt}$ (equal to $\mathrm{mm}^{2} \mathrm{~s}^{-1}$ ) in the neat oil to $15.95 \mathrm{cSt}$ in the blend of $20 \mathrm{vol}-\%$ butanol and 80 vol-\% jatropha oil [28], while the calorific value was almost unchanged $\left(39.8 \mathrm{MJ} \mathrm{kg}^{-1}\right.$ vs. $\left.39.0 \mathrm{MJ} \mathrm{kg}^{-1}\right)$. Kinematic viscosity has also been reported to decrease in butanol-diesel blends, but to a far smaller degree [29]. 
The surface tension for rapeseed oil at $22.5^{\circ} \mathrm{C}$ as reported in the present study $\left(32.9 \mathrm{mN} \mathrm{m}^{-1}\right)$ is comparable to a value measured by Esteban et al. [30]. In that study [30], surface tension of rapeseed oil could be reduced from $33.8 \mathrm{~m} \mathrm{~N} \mathrm{~m}^{-1}$ to $26.1 \mathrm{mN} \mathrm{m}^{-1}$ by heating the oil to $120^{\circ} \mathrm{C}$. Additionally, surface tension of around $26 \mathrm{mN} \mathrm{m}^{-1}$ is shown by diesel at a temperature of $40^{\circ} \mathrm{C}$ [30]. Thus, blending rapeseed oil with 30 vol-\% butanol had a comparable effect on surface tension as heating diesel to $40{ }^{\circ} \mathrm{C}$.

Density of the rapeseed oil from Avena Kantvik $\left(920 \mathrm{~kg} \mathrm{~m}^{-3}\right)$ was very close to the $921 \mathrm{~kg} \mathrm{~m}^{-3}$ measured for rapeseed oil by Goering et al. [31]. The density of the rapeseed oil, the BU10-RSO and BU20-RSO blends were very close to the values measured by Laza and Bereczky [14]. However, the cold filter plugging point for the BU20-RSO and BU30-RSO blends were well below zero in our study $\left(-6^{\circ} \mathrm{C}\right.$ and $-13{ }^{\circ} \mathrm{C}$, respectively), while just around zero ${ }^{\circ} \mathrm{C}$ for $10 \%$ and $20 \%$ butanol-rapeseed oil blends in the study by Laza and Bereczky [14]. The reason for this difference can only be speculated. Rapeseed oils in both studies were commercial products. Laza and Bereczky [14] followed standard ASTM D 6371 when determining CFPP, which is technically equivalent to the EN 116 standard followed in the present study. However, the fatty acid composition of the rapeseed oil was not measured in the present study and nor was it given in the study by Laza and Bereczky [14]. Variation in fatty acid composition or impurities might cause differences in cold filter plugging point. Overall, Laza and Bereczky [14] concluded from their more extensive studies that rapeseed oil-higher alcohol blends are feasible alternative fuels for diesel engines, with the proviso that additional engine tests should show no adverse effects on engine operation.

In the following discussion, the results from the present study are compared with limits set in the standards for EU automotive fuels, biodiesel and marine fuels. Even though the kinematic viscosity of RSO was efficiently reduced by mixing with either ethanol or butanol, the lowest measured value of $11.26 \mathrm{~mm}^{2} \mathrm{~s}^{-1}$ for BU30-RSO was still more than double the maximum value (limits minimum 3.50, maximum $5.00 \mathrm{~mm}^{2} \mathrm{~s}^{-1}$ ) as set in the standard for biodiesel SFS-EN 14214:2012 [32], and the value (limits minimum 2.000, maximum $4.500 \mathrm{~mm}^{2} \mathrm{~s}^{-1}$ ) as set in the standard for automotive diesel SFS-EN 590:2013 [12]. Kinematic viscosity of the BU30-RSO blend at $40{ }^{\circ} \mathrm{C}\left(11.26 \mathrm{~mm}^{2} \mathrm{~s}^{-1}\right)$ was the only result that almost complied with the standard specification for marine fuels ISO 8217:2017 [33] for distillate marine oil grades DMB/DFB (limits minimum 2.000, maximum $11.00 \mathrm{~mm}^{2} \mathrm{~s}^{-1}$ ). Kinematic viscosity at $40{ }^{\circ} \mathrm{C}$ of all alcohol-rapeseed oil blends were within limits applicable to residual marine fuels with the exception of grade RMA. However, the results cannot be conclusively compared since kinematic viscosity is determined at $50{ }^{\circ} \mathrm{C}$ for residual marine fuels, instead of the $40{ }^{\circ} \mathrm{C}$ test point for distillate marine oil.

The density of the neat rapeseed oil and all the blends complied with limits for residual marine fuel grades (max. $920.0 \mathrm{~kg} \mathrm{~m}^{-3}$ for grade RMA and higher for the other RM fuels). The densities of the BU20-RSO and BU30-RSO blends were also within the limits applicable to distillate marine oils DMB/DFB (max. $900.0 \mathrm{~kg} \mathrm{~m}^{-3}$ ). The density of blend BU30-RSO also fell within the limits for DMA/DFA and DMZ/DFZ (max. $890.0 \mathrm{~kg} \mathrm{~m}^{-3}$ ) as set in standard ISO 8217 for marine fuels [33]. Moreover, the densities of the BU20-RSO and BU30-RSO blends also complied with the $860-900 \mathrm{~kg} \mathrm{~m}^{-3}$ density requirement of the SFS-EN 14214 standard for fatty acid methyl esters (FAME) for use in diesel engines and heating applications [32].

The cold filter plugging point of the BU20-RSO and BU30-RSO blends complied with for instance grade $C$ for summer season in Finland (at maximum $-5^{\circ} \mathrm{C}$, National Annex to SFS-EN 590 [12]) in the standard for automotive fuels SFS-EN 590 [12]. The standard for marine fuels does not specify values for CFPP, although these shall be reported for winter grades of some of the distillate marine fuels.

While blending different fuels can improve physical-chemical properties, it may also lead to operating complications or increases in emissions. Many studies report results from mixing alcohol, vegetable oil, biodiesel and diesel in different combinations. Fewer publications report properties of alcohol-vegetable oil blends and operational experiences in CI engines. Mixing ethanol with vegetable oil (Honge oil) lowered viscosity, improved volatility, showed better combustion and lower carbon 
deposits as compared to straight vegetable oil in the study by Rao and Premkumar [34]. The authors also reported that nitrogen oxides, carbon monoxides and smoke emissions were reduced with an increasing proportion of ethanol in the blend, and were closer to diesel-fuelled engine emissions than when the engine was fuelled with the straight vegetable oil.

Labeckas et al. [35] investigated the effect of ethanol and rapeseed oil blends on engine performance and exhaust emissions. They stated that ethanol inclusion up to 7.5 vol-\% reduced, e.g., $\mathrm{NO}, \mathrm{NO}_{\mathrm{x}}$, $\mathrm{HC}$ and $\mathrm{CO}_{2}$ emissions as well as smoke opacity and exhaust temperature. At the same time, however, the ethanol-rapeseed oil blends could increase $\mathrm{NO}_{2}, \mathrm{NO}_{2} / \mathrm{NO}_{\mathrm{x}}$ and $\mathrm{CO}$ emissions.

Goering et al. [31] tested two microemulsions of aqueous ethanol (17 and 13 vol-\%) in soybean oil with 1-butanol (21 and 33 vol-\%) in a diesel engine in comparison with No. 2 diesel. Viscosity of the emulsions at $37.8{ }^{\circ} \mathrm{C}$ were 8.77 and $6.77 \mathrm{~mm}^{2} \mathrm{~s}^{-1}$. Although having a $19 \%$ lower heating value, one of the emulsions was almost as efficient in engine power production as when the engine was run on diesel. However, brake-specific fuel consumption of the microemulsions was higher than with diesel fuel [31].

Mat et al. [9] reported that an addition of 20\% rapeseed oil and 10\% n-butanol (also known as 1-butanol) to diesel reduced $\mathrm{CO}_{2}$ emissions at all engine speeds when compared to diesel. However, $\mathrm{NO}_{\mathrm{x}}$ was increased right across the engine-speed range, $\mathrm{CO}$ was elevated at low and medium speeds and $\mathrm{HC}$ was evaluated at low engine-speed.

Holúbek et al. [36] studied the long-term operation of a diesel power-generator running on a blend of $10 \%$ n-butanol-20\% rapeseed oil- $70 \%$ diesel fuel. The generator was operated for $70 \mathrm{~h}$. Production of emissions increased after $70 \mathrm{~h}$ of operation when run on the fuel blend as compared to diesel fuel alone. Fuel blend consumption was also higher after $70 \mathrm{~h}$ of operation than when operating the generator with standard diesel fuel. Smoke and particles production increased when run on the blend.

Čedik et al. [37] investigated the effects of sunflower and rapeseed oil on the production of solid particles and on diesel engine performance. The tested blends were $5 \%$ and $20 \%$ sunflower-diesel and rapeseed-diesel blends. The authors noticed a $2-3 \%$ torque and power uplift in operation for both types of blends as compared to diesel. Particle size increased slightly, but the production of solids fell. However, the production of solid particles rose during engine idling.

In summary, blends of alcohol, vegetable oil and diesel can have positive and negative or no effects at all on $\mathrm{CI}$ engine operation and emissions. Only individual studies for new blends including durability tests can reliably disclose the outcomes.

The viscosity values measured in the present study are acceptable for medium-speed engines. Based on the high viscosity values, the blends appear suitable for use in heavy fuel oil driven engines in power plants and marine engines. In these applications, suitable viscosity during injection is otherwise achieved by heating the fuel oil.

The components' production chains have to be carefully analysed in order to make sure that novel fuel blends are truly sustainable. Both ethanol and butanol can be produced in either biological or petrochemical processes [38,39], and only the use of alcohols produced through fermentation will help to generate a genuinely renewable fuel blend. Global bioethanol production was estimated to be $8.46 \times 10^{10}$ litres in 2011, with a production of $5467 \times 10^{6}$ litres in the EU-27 states and more than half of the global bioethanol produced by the United States [39]. Butanol production in ABE (acetone, butanol, ethanol) fermentation has traditionally given a low yield and industrial production had been discontinued by the 1980s, while chemical synthesis was maintained [38]. Several facilities are said to have started production of biobutanol in the mid-2000s [38], and future production figures will show to what extent biobutanol might be used in fuel blends. Rapeseed oil is a fully renewable product, but production of rapeseed for fuel is competing with food production for land area. New feedstocks for oils are sought and one such feedstock that has been identified is algae (e.g., [40]). Butanol production has to be made more efficient for the existing substrates and new substrates need to be identified, to ensure production of butanol is sustainable for the future [20]. Butanol is considered a promising fuel, especially if new technical solutions can reduce its production costs [41]. One of the possible feedstocks for butanol production is glycerol, a by-product of the transesterification of vegetable oils 
and animal fats into biodiesel. Using glycerol from biodiesel production in butanol production might help improve sustainability [38].

\section{Conclusions}

This study tested a set of rapeseed oil-alcohol blends, evaluating their stability and some key fuel properties: kinematic viscosity, density, surface tension and cold filter plugging point. The results were compared with fuel standards ISO 8217 [33], SFS-EN 590 [12] and SFS-EN 14214 [32]. The purpose of the study was to further investigate different options for developing alternative, renewable fuels.

Alternative stable fuel blends were achieved by blending butanol and rapeseed oil in proportions of up to 30 vol- $\%$ butanol, or 5 vol- $\%$ ethanol. Blending rapeseed oil with butanol decreased kinematic viscosity, density and surface tension. The strongest effect was on kinematic viscosity, the least on density. Nevertheless, kinematic viscosity of all blends clearly remained above the limits set in standards for automotive diesel fuel and biodiesel. Cold filter plugging point was the only value that could be reached by two of the butanol-rapeseed oil blends in accordance with limits for summer season grade in Finland for automotive diesel standard SFS-EN 590 [12]. Therefore, the alcohol-rapeseed oil blends tested here are not appropriate for use in on-road vehicles.

The density of all blends and the neat rapeseed oil complied with density limits for residual marine fuels. Even their kinematic viscosity values at $40^{\circ} \mathrm{C}$ were within the requirements for residual marine fuels at $50{ }^{\circ} \mathrm{C}$. The $30 \%$ butanol- $70 \%$ rapeseed oil blend complied with the density limit and almost with the kinematic viscosity limit of some distillate marinefuel. These results indicate that butanol-rapeseed oil blends appear most suitable for use in power plants and marine engines. More detailed analyses on blend properties and various engine tests would be needed before these blends could be recommended for use in commercial engines.

Author Contributions: Conceptualisation, K.S. and H.S.; methodology, K.S., H.S. and S.H.; investigation, R.H. and S.H.; visualisation, R.H. and C.N.; writing-original draft preparation, C.N.; writing-review and editing, R.H., K.S., H.S., S.H. and S.N.; supervision, S.N. All authors have read and agreed to the published version of the manuscript.

Funding: This research received no external funding.

Acknowledgments: This research was supported by the University of Vaasa, School of Technology and Innovations.

Conflicts of Interest: The authors declare no conflict of interest.

\section{References}

1. European Commission. 2030 Climate and Energy Framework. Available online: https://ec.europa.eu/clima/ policies/strategies/2030_en (accessed on 9 January 2020).

2. U.S. Energy Information Administration (EIA). International Energy Outlook 2019. Available online: https://www.eia.gov/tools/faqs/faq.php?id=527\&t=1 (accessed on 8 January 2020).

3. Chia, S.R.; Ong, H.C.; Chew, K.W.; Show, P.L.; Phang, S.-M.; Ling, T.C.; Nagarajan, D.; Lee, D.-J.; Chang, J.-S. Sustainable approaches for algae utilisation in bioenergy production. Renew. Energy 2018, 129, 838-852. [CrossRef]

4. Demirbas, A. Competitive liquid biofuels from biomass. Appl. Energy 2011, 88, 17-28. [CrossRef]

5. Sadeghinezhad, E.; Kazi, S.N.; Sadeghinejad, F.; Badarudin, A.; Mehrali, M.; Sadri, R.; Safaei, M.R. A comprehensive literature review of bio-fuel performance in internal combustion engine and relevant costs involvement. Renew. Sustain. Energy Rev. 2014, 30, 29-44. [CrossRef]

6. Sathaye, J.; Lucon, O.; Rahman, A.; Christensen, J.; Denton, F.; Fujino, J.; Heath, G.; Kadner, S.; Mirza, M.; Rudnick, H.; et al. Renewable energy in the context of sustainable development. In IPCC Special Report on Renewable Energy Sources and Climate Change Mitigation; Edenhofer, O., Pichs-Madruga, R., Sokona, Y., Seyboth, K., Matschoss, P., Kadner, S., Zwickel, T., Eickemeier, P., Hansen, G., Schlömer, S., et al., Eds.; Cambridge University Press: Cambridge, UK; New York, NY, USA, 2011; pp. 707-790.

7. Kumar, B.R.; Saravanan, S. Use of higher alcohol biofuels in diesel engines: A review. Renew. Sustain. Energy Rev. 2016, 60, 84-115. [CrossRef] 
8. Niemi, S.A.; Laurén, M.J.; Jokiniemi, H.T.; Ahokas, J.; Kallio, P.-M.; Laukka, M.; Laiho, V.O.K. Effects of vegetable oil heating on the exhaust emissions of an off-road diesel engine. In Proceedings of the 5th International Colloquium Fuels 2005, Technische Akademie Esslingen, Ostfildern, Germany, 12-13 January 2005; pp. 71-81.

9. Mat, S.C.; Idroas, M.Y.; Hamid, M.F.; Zainal, Z.A. Performance and emissions of straight vegetable oils and its blends as a fuel in diesel engine: A review. Renew. Sustain. Energy Rev. 2018, 82, 808-823. [CrossRef]

10. Dabi, M.; Saha, U.K. Application potential of vegetable oils as alternative to diesel fuels in compression ignition engines: A review. J. Energy Inst. 2019, 92, 1710-1726. [CrossRef]

11. Guibet, J.C. Fuels and Engines; Institut Français du Pétrole Publications, Éditions Technip: Paris, France, 1999; p. 786.

12. Automotive Fuels. Diesel. Requirements and Test Methods; SFS-EN 590:2013; Finnish Standards Association: Helsinki, Finland, 2013; pp. 1, 13.

13. Blin, J.; Brunschwig, C.; Chapuis, A.; Changotade, O.; Sidibe, S.S.; Noumi, E.S.; Girard, P. Characteristics of vegetable oils for use as fuel in stationary diesel engines-towards specifications for a standard in West Africa. Renew. Sustain. Energy Rev. 2013, 22, 580-597. [CrossRef]

14. Laza, T.; Bereczky, Á. Basic fuel properties of rapeseed oil-higher alcohols blends. Fuel 2011, 90, 803-810. [CrossRef]

15. No, S.-Y. Application of straight vegetable oil from triglyceride based biomass to IC engines-A review. Renew. Sustain. Energy Rev. 2017, 69, 80-97. [CrossRef]

16. European Biodiesel Board. 2003-2019. Available online: https://www.ebb-eu.org/biodiesel.php (accessed on 14 January 2020).

17. Estevez, R.; Aguado-Deblas, L.; Bautista, F.M.; Luna, D.; Luna, C.; Calero, J.; Posadillo, A.; Romero, A.A. Biodiesel at the crossroads: A critical review. Catalysts 2019, 9, 1033. [CrossRef]

18. Hansen, A.C.; Zhang, Q.; Lyne, P.W.L. Ethanol-diesel fuel blends-A review. Bioresour. Technol. 2005, 96, 277-285. [CrossRef] [PubMed]

19. Jin, C.; Zhang, X.; Geng, Z.; Pang, X.; Wang, X.; Ji, J.; Wang, G.; Liu, H. Effects of various co-solvents on the solubility between blends of soybean oil with either methanol or ethanol. Fuel 2019, 244, 461-471. [CrossRef]

20. Jin, C.; Yao, M.; Liu, H.; Lee, C.-F.F.; Ji, J. Progress in the production and application of n-butanol as a biofuel. Renew. Sustain. Energy Rev. 2011, 15, 4080-4106. [CrossRef]

21. SVM 3000/G2 Stabinger Viscometer Instruction Manual; Anton Paar GmbH: Graz, Austria, 2011.

22. Novotny-Farkas, F.; Böhme, W.; Stabinger, H.; Belitsch, W. The Stabinger Viscometer-A Unique New Instrument for oil Service Laboratories. Available online: https:/www.oetg.at/fileadmin/Dokumente/oetg/ Proceedings/WTC_2001_files/html/M-68-10-765-BELITSCH.pdf (accessed on 28 January 2020).

23. Automatic Tensiometer TD 2 Operating Instructions; Lauda Dr. R. Wobser GmbH \& CO.KG: Lauda-Königshofen, Germany, 1998.

24. Open University at University of Jyväskylä, Department of Chemistry. Surfactants. Available online: https://koppa.jyu.fi/avoimet/kemia/kems448/suomeksi/ohjeet/liuokset/pintajannitys (accessed on 7 November 2019). (In Finnish)

25. Callisto 100 Instruction Manual; H26IB001EN-F; Anton Paar GmbH: Graz, Austria, 2018; p. 11.

26. Diesel and Domestic Heating Fuels. Determination of Cold Filter Plugging Point. Stepwise Cooling Bath Method; SFS-EN 116:2015; Finnish Petroleum and Biofuels Association: Helsinki, Finland, 2015.

27. Lapuerta, M.; Rodrígez-Fernández, J.; Fernández-Rodrígez, D.; Patiño-Camino, R. Modeling viscosity of butanol and ethanol blends with diesel and biodiesel fuels. Fuel 2017, 199, 332-338. [CrossRef]

28. Kumar, N.; Bansal, S.; Pali, H.S. Blending of Higher Alcohols with Vegetable Oil Based Fuels for Use in Compression Ignition Engine; SAE Technical Paper 2015-01-0958; SAE International: Warrendale, PA, USA, 2015. [CrossRef]

29. Lapuerta, M.; García-Contreras, R.; Campos-Fernández, J.; Dorado, M.P. Stability, lubricity, viscosity, and cold-flow properties of alcohol-diesel blends. Energy Fuels 2010, 24, 4497-4502. [CrossRef]

30. Esteban, B.; Riba, J.-R.; Baquero, G.; Puig, R.; Rius, A. Characterization of the surface tension of vegetable oils to be used as fuel in diesel engines. Fuel 2012, 102, 231-238. [CrossRef]

31. Goering, C.E.; Schwab, A.W.; Campion, R.M.; Pryde, E.H. Soyoil-ethanol microemulsions as diesel fuel. Trans. ASAE 1983, 26, 1602-1604, 1607. [CrossRef] 
32. Liquid Petroleum Products. Fatty Acid Methyl Esters (FAME) for Use in Diesel Engines and Heating Applications-Requirements and Test Methods; SFS-EN 14214:2012; Finnish Standards Association: Helsinki, Finland, 2013; pp. 1, 17.

33. Petroleum Products-Fuels (Class. F)—Specifications of Marine Fuels; ISO 8217:2017(E); International Organization for Standardization: Geneva, Switzerland, 2017; p. 23.

34. Rao, N.D.; Premkumar, B.S. Effect of ethanol addition to straight vegetable oil on performance and emission characteristics of compression ignition engine. Int. J. Sci. Eng. Res. 2012, 3, 6.

35. Labeckas, G.; Slavinskas, S.; Pauliukas, A. The effect of rapeseed oil blending with ethanol on engine performance and exhaust emissions. J. KONES Powertrain Transp. 2007, 14, 331-338.

36. Holúbek, M.; Pexa, M.; Čedik, J.; Mader, D. Effect of long-term operation of combustion engine running on n-butanol-rapeseed oil-diesel fuel blend. Agron. Res. 2019, 17, 1001-1012.

37. Čedik, J.; Pexa, M.; Holúbek, M.; Mader, D.; Pražan, R. Effect of sunflower and rapeseed oil on production of solid particles and performance of diesel engine. Agron. Res. 2018, 16, 985-996.

38. Ndaba, B.; Chiyanzu, I.; Marx, S. n-Butanol derived from biochemical and chemical routes: A review. Biotechnol. Rep. 2015, 8, 1-9. [CrossRef] [PubMed]

39. European Technology and Innovation Platform (ETIP) Bioenergy. Ethanol Fact Sheet. State of the Art. Available online: http://www.etipbioenergy.eu/index.php?option=com_content\&view=article\&id=329 (accessed on 21 January 2020).

40. Brennan, L.; Owende, P. Biofuels from microalgae-a review of technologies for production, processing, and extractions of biofuels and co-products. Renew. Sustain. Energy Rev. 2010, 14, 557-577. [CrossRef]

41. Nilsson, R.; Bauer, F.; Mesfun, S.; Hulteberg, C.; Lundgren, J.; Wännström, S.; Rova, U.; Berglund, K.A. Techno-economics of carbon preserving butanol production using a combined fermentative and catalytic approach. Bioresour. Technol. 2014, 161, 263-269. [CrossRef] [PubMed]

(C) 2020 by the authors. Licensee MDPI, Basel, Switzerland. This article is an open access article distributed under the terms and conditions of the Creative Commons Attribution (CC BY) license (http://creativecommons.org/licenses/by/4.0/). 